\title{
Blastic Crisis in Chronic Granulocytic Leukaemia. Cytochemical, Cytogenetic, and Autoradiographic Studies in Four Cases
}

\author{
F. HAMMOUDA,* M.B., CH.B., D.M.SC. ; D. QUAGLINO,* M.D., PH.D. \\ F. G. J. HAYHOE,* M.A., M.D., M.R.C.P.
}

Brit. med. F., 1964, 1, 1275-1281

The terminal transformation of chronic granulocytic leukaemia into a cytologically acute form, with an increasing proportion of nucleolated blast cells in the bone-marrow and peripheral blood and eventual development of a picture closely resembling that of acute leukaemia, is associated with cytochemical changes of a rather surprising kind. We have earlier drawn attention to some of these (Quaglino, 1961a ; Hayhoe, 1963 ; Hayhoe et al., 1964). Perhaps the most striking is an increase in the alkaline phosphatase content of mature polymorphs from the very low level almost invariably found in the chronic phase of the disease to a level within or above the normal range. This observation has been confirmed by others (Fischer et al., 1963), and raises interesting questions in relation to the capacity of leucocyte alkaline phosphatase to provide a functional marker of activity in chromosome 21 (Alter et al., 1963). Another unexpected cytochemical finding concerns the glycogen content of the primitive cells in blastic crisis, where the pattern has often proved to be coarser and more strongly positive than in the myeloblasts and promyelocytes present either in the chronic phase of the disease or in acute myeloid leukaemia.

Cytogenetic studies in the acute phase of chronic granulocytic leukaemia have not yet been reported in very large numbers, but a review by Court Brown and Tough (1963) gives some details of 13 cases studied by their own Edinburgh group, and refers to cases reported by Nowell and Hungerford (1961) and by Adams et al. (1961). Hammouda (1963) has also briefly reported a case, described in more detail in the present paper, where the patient first presented in what seems likely to have been an acute phase of the disease. From these reports it is already clear that the cytogenetic pattern of cells in the stage of acute transformation often differs from the almost uniform pattern of chronic granulocytic leukaemia in the chronic phase, with its modal number of 46 chromosomes, one small acrocentric, probably of pair 21 , being replaced by the characteristic minute $\mathrm{Ph}^{1}$ chromosome. The differences vary, but usually involve the emergence of one or more additional abnormal cell lines, commonly $\mathrm{Ph}^{1}+$, but having either constant aneuploidy or diploidy with an abnormal karyotypic analysis probably resulting from deletions or translocations. Neither in acute crisis of chronic granulocytic leukaemia nor in originally acute leukaemias have the recorded abnormalities proved sufficiently uniform or consistent to allow a close identity of chromosomal disorder to be established between the cell lines of the former state and those of any subdivision of the latter, and it is not therefore possible to say as yet that the cells of blastic crisis cytogenetically resemble those of acute myeloblastic leukaemia rather than those of acute monocytic, lymphoblastic, or other form of acute leukaemia.

When cultures of leucocytes from the peripheral blood are used for chromosome studies in leukaemia, results compare more closely with those from direct cultures of bone-marrow cells when phytohaemagglutinin (P.H.A.) or other mitotic stimulant is not added. In cultures of peripheral cells from chronic granulocytic leukaemia, for example, virtually all chromosome preparations made in the chronic phase of the

* Department of Medicine, University of Cambridge. disease show the $\mathrm{Ph}^{1}$ chromosome when P.H.A. is not used, whereas use of P.H.A. induces mitotic division in non-granulocytic cells which give figures without the $\mathrm{Ph}^{1}$ chromosome, so that the final picture shows a mixture of $\mathrm{Ph}^{1}+$ and $\mathrm{Ph}^{1}-$ cell lines. It is a reasonable assumption that the cells from leukaemic peripheral blood which divide without stimulation by P.H.A. are those which have already a capacity for deoxyribonucleic acid (D.N.A.) synthesis and would accordingly take up a tritiated thymidine label in vitro. If more than one persistent cell line is demonstrable cytogenetically it is therefore possible that a study of those cells from the peripheral blood which incorporate tritiated thymidine or those developing capacity to synthesize D.N.A. in short-term culture without P.H.A. might reveal that they fall into more than one category on simple cytological criteria. In this way a lead might be given towards solving the difficult problem of allocation of metaphase spreads to particular cytological lines.

With all these considerations in mind we have carried out a combined study of cells from the blood or bone-marrow of patients during the blastic phase of chronic granulocytic leukaemia, using cytochemical, cytogenetic, and autoradiographic techniques, and now report the findings and discuss possible correlations between them.

\section{Materials and Methods}

Material for this study was drawn from four patients, three having undoubtedly acute transformation of chronic granulocytic leukaemia and the fourth probably so.

The cytochemical techniques used in this study consisted of an azo-dye method for alkaline phosphatase (Hayhoe and Quaglino, 1958), the periodic-acid-Schiff (P.A.S.) reaction (McManus, 1946), the Sudan black B reaction (Sheehan and Storey, 1947), a modified Graham-Knoll peroxidase technique (Quaglino and Flemans, 1958), the technique of Kaplan et al. (1954) for demonstrating siderotic granules, and methods for phosphorylases (Quaglino and Hayhoe, 1962) and for demonstrating succinic, alpha-glycerophosphate, and lactic dehydrogenases (Quaglino, 1961b). Semi-quantitative scoring methods for leucocyte alkaline phosphatase, the P.A.S. reaction in blast cells and erythroblasts, and free iron in erythroblasts were as described by Hayhoe and Quaglino $(1958,1960)$ and Quaglino and Hayhoe (1959, 1960).

Autoradiographic studies on nucleoprotein synthesis were carried out using tritiated thymidine (from the Radiochemical Centre, Amersham, England). Preparations were made from $1-\mathrm{ml}$. cell suspensions of heparinized peripheral blood, incubated for one hour with $0.1 \mathrm{ml}$. of tritiated thymidine diluted to an activity of $5 \mu \mathrm{c} . / \mathrm{ml}$. The smears were left in contact with Kodak AR10 stripping film for six days and after photographic processing were counterstained by May-Grünwald-Giemsa or P.A.S. techniques.

Cytogenetic studies were performed on the four cases by setting up peripheral blood cultures using a modification of the method described by Moorhead et al. (1960) Phytohaemagglu- 
tinin was used in some cultures but was omitted from most. Spreads were made after intervals of incubation varying from 24 to 70 hours. Details are given in Tables I to IV. Direct cultures of bone-marrow were set up using a modification of the method of Tjio and Whang (1962).

\section{Results}

The cytochemical, autoradiographic, and cytogenetic findings obtained from the four patients examined are presented separately for each case, together with details of treatment and

TABLE I.-Results in Case 1

\begin{tabular}{|c|c|c|c|c|c|c|c|c|c|c|c|c|}
\hline $\begin{array}{l}\text { Type of } \\
\text { Culture }\end{array}$ & Date & $\begin{array}{c}\text { Haematological } \\
\text { Findings }\end{array}$ & Treatment & $\begin{array}{c}\text { Time of } \\
\text { Harvesting }\end{array}$ & Total & $>48$ & 48 & 47 & 46 & 45 & $<45$ & Comment \\
\hline $\begin{array}{l}1 . \\
\text { Peripheral } \\
\text { blood with } \\
\text { P.H.A. }\end{array}$ & $13 / 3 / 63$ & $\begin{array}{l}\text { Hb } 9 \text { g. } \\
\text { 114,0o.C. } \\
\text { myelocytes and } \\
\text { byasts } 3 \% . \\
\text { Myelocytes } 23 \%\end{array}$ & $\begin{array}{l}\text { Previous } \\
\text { D.X.R. to } \\
\text { spleen }\end{array}$ & $\begin{array}{l}24,47 \text {, and } \\
55 \text { hours }\end{array}$ & 45 & 1 & 1 & 4 & 26 & 2 & 11 & $\begin{array}{l}10 \text { of the } 45 \text { figures counted were } \mathrm{Ph}^{1}+ \\
\text { and all were analysed. } 4 \text { had } 5 \text { small } \\
\text { acrocentrics, including the } \mathrm{Ph}^{1} \\
\text { chromosome, and in } 2 \text { cases a second } \\
\text { small acrocentric similar to the } \mathrm{Ph}^{1} \\
\text { was present; } 6 \text { cells had } 4 \text { small } \\
\text { acrocentrics, including the } \mathrm{Ph}^{1} \\
\text { chromosome }\end{array}$ \\
\hline $\begin{array}{l}\text { Peripher } \\
\text { Periol } \\
\text { blood with } \\
\text { P.H.A. }\end{array}$ & $20 / 3 / 63$ & $\begin{array}{l}\text { Hb 9.1 g. W.C. } \\
157,000 \text {. Pro- } \\
\text { myelocytes and } \\
\text { blasts } 9 \% . \cdot \\
\text { Myelocytes } 28 \%\end{array}$ & $\begin{array}{l}\text { Busulphan } \\
4 \mathrm{mg} . \\
\text { daily }\end{array}$ & $\begin{array}{c}48 \text { and } 70 \\
\text { hours }\end{array}$ & 56 & 3 & 3 & 3 & 32 & 6 & 9 & $\begin{array}{l}23 \text { of the } 56 \text { figures counted were } \mathrm{Ph}^{1}+ \\
13 \mathrm{Ph}^{1}+\text { figures were fully analysed; } \\
8 \mathrm{had}^{5} \text { small acrocentrics, inclyuding } \\
\text { the } \mathrm{Ph}^{1} \text { chromosomes } 5 \text { had } 4 \text { small } \\
\text { acrocentrics, including in } 2 \text { cases a } \\
\text { single } \mathrm{Ph}^{1} \text { chromosome and in } 3 \text { two } \\
\text { minute acrocentrics resembling the }\end{array}$ \\
\hline $\begin{array}{l}\text { 3. } \\
\text { Peripheral } \\
\text { blood } \\
\text { without } \\
\text { P.H.A. }\end{array}$ & $4 / 7 / 63$ & $\begin{array}{l}\text { Hb } 12.4 \mathrm{~g} . \text { W.C. } \\
101,260 . \text { Pro- } \\
\text { myelocytes and } \\
\text { blasts } 1 \% . \\
\text { Myelocytes } 21 \%\end{array}$ & $\begin{array}{l}\text { Busulphan } \\
4 \mathrm{mg} . \\
\text { Prednisone } \\
20 \mathrm{mg} . \\
\text { daily }\end{array}$ & 42 hours & 8 & - & - & - & 6 & 2 & - & $\begin{array}{l}\text { All } 8 \text { figures were } \mathrm{Ph}^{1}+\text {, and all were } \\
\text { fully analysed. } 3 \text { showed } 4 \text { small } \\
\text { acrocentrics, including Phy } 5 \text {, } 5 \text {, } 5 \text { showed } 5 \text { small acrocentrics, including } \\
\text { showed } 2 \text { cases a single } \mathrm{Ph}^{1} \text { and in } 3 \text { two } \\
\text { in }\end{array}$ \\
\hline $\begin{array}{l}\text { 4. } \\
\text { Peripheral } \\
\text { blood } \\
\text { without } \\
\text { P.H.A. }\end{array}$ & $31 / 10 / 63$ & $\begin{array}{l}\text { Hb } 12 \text { g. W.C. } \\
78,020 . \\
\text { Blasts } 36 \% \% \\
\text { Myelocytes } 6 \%\end{array}$ & $\begin{array}{l}\text { M.P. } \\
100 \text { mg. } \\
\text { Prednisone } \\
5 \text { mg. daily }\end{array}$ & 48 & 35 & - & - & 1 & 25 & 7 & 2 & $\begin{array}{l}\text { All } 35 \text { figures were } \mathrm{Ph}^{1}+.30 \text { were fully } \\
\text { analysed } 28 \text { showed } 5 \text { small acro- } \\
\text { centrics, including } 1 \mathrm{Ph}^{1} \text { chromosome } \\
\text { in } 18 \text { and } 2 \mathrm{Ph}^{1} \text { chromosomes in } 10 ; \\
2 \text { had only } 4 \mathrm{small}^{1} \text { acrocentrics, } \\
\text { including a single } \mathrm{Ph}^{1} \text {. }\end{array}$ \\
\hline
\end{tabular}

Note 1: In cultures 1 and 2 all $\mathrm{Ph}^{1}$ - figures showed normal karyotypes. Note 2: All figures with extra small acrocentrics showed only 5 chromosomes in the 13-15 group. M.P. = Mercaptopurine.

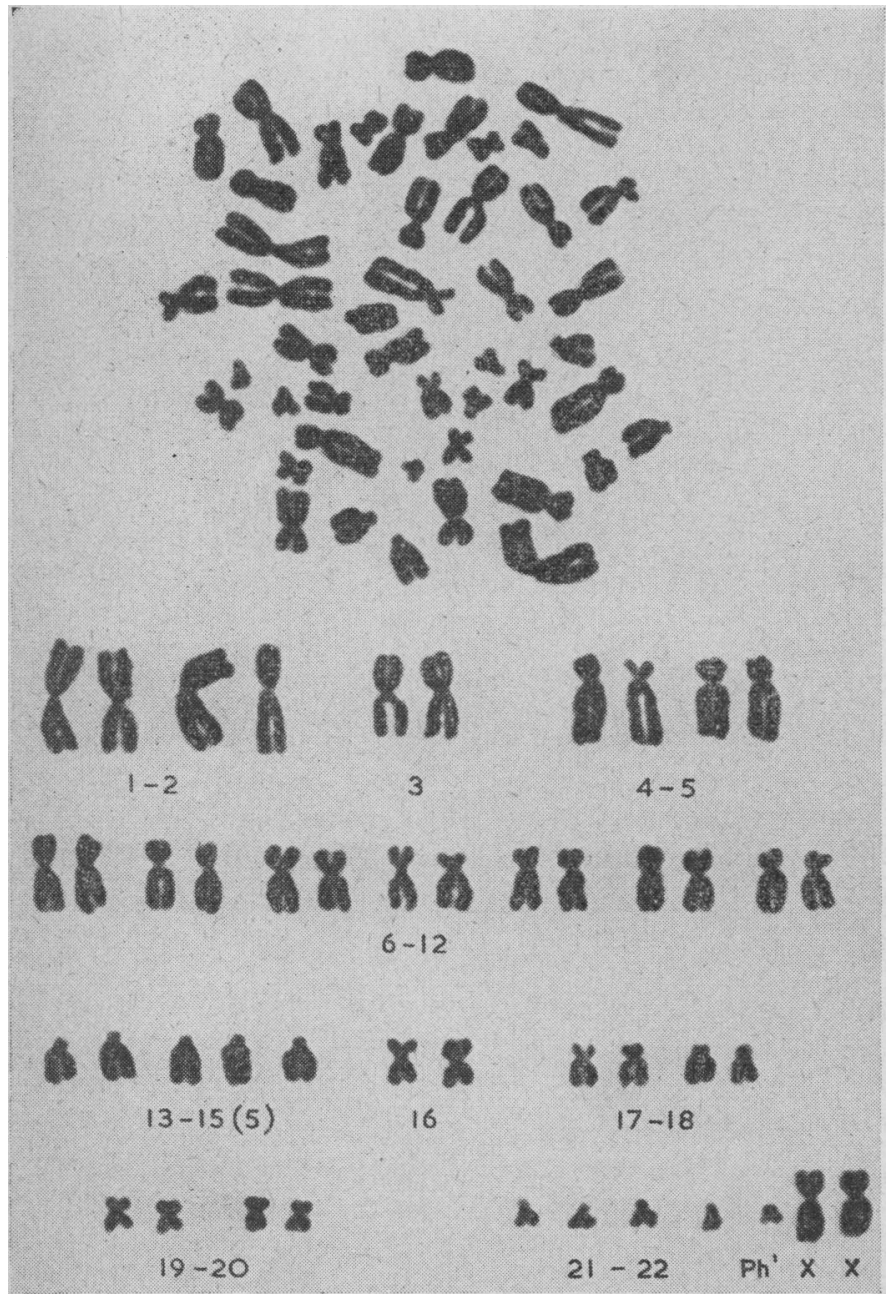

FIG. 1.-Diploid metaphase spread and karyotype from Case 1, showing five large acrocentrics and five small acrocentrics, including one $\mathbf{P h}^{1}$ chromosome.

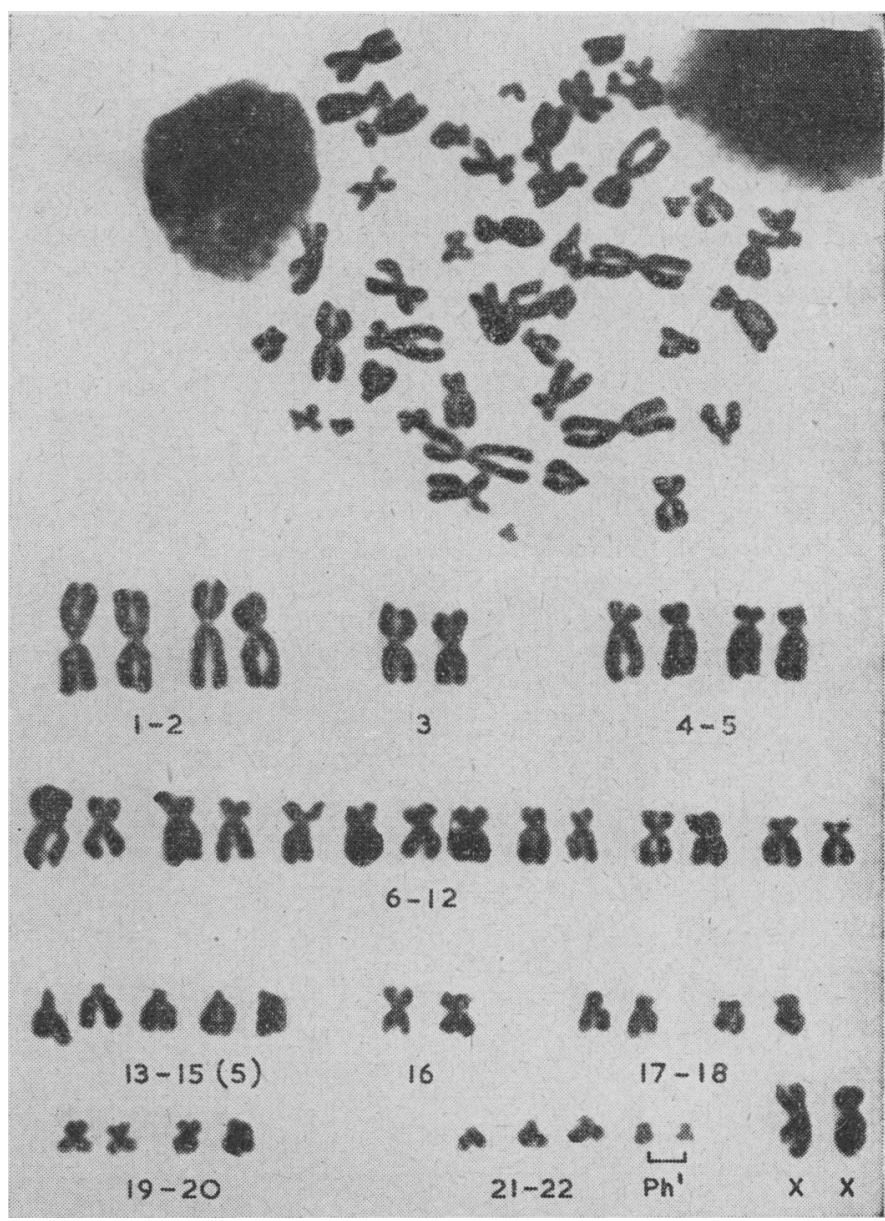

Fig. 2.-Diploid metaphase spread and karyotype from Case 1, showing five large acrocentrics and five small acrocentrics, including two minute chromosomes resembling $\mathrm{Ph}^{1}$. 
a brief summary of the clinical history and of the more relevant haematological findings.

\section{Case 1}

A 14-year-old girl was first diagnosed as suffering from chronic granulocytic leukaemia in March 1963. After several courses of radiotherapy to the spleen she was started on busulphan (2-6 mg. daily), which induced a partial remission. In October, because of the presence of increasing numbers of primitive cells $(29 \%)$ despite continued treatment with busulphan, the regime was altered, and mercaptopurine (100 mg. daily) and prednisone (10-20 mg. daily) were given. A state of partial haematological and clinical control persisted (November 1963).

Before the onset of acute transformation of the leukaemic process this patient had shown a low alkaline phosphatase score $(0-3)$ in mature granulocytes and a negative P.A.S. reaction in blast cells.
On 22 October, when the total white-cell count was 126,000 / c.mm., with $37 \%$ blast cells, the cytochemical findings were as follows :

1. Alkaline phosphatase score : 28.

2. P.A.S. score in blast cells : 148 ( $87 \%$ of the primitive cells showed fine, moderately coarse, and coarse granules).

3. Sudan black $B$ reaction : $85 \%$ of blast cells were negative, while the remainder showed faint localized positivity. A proportion of the primitive cells also showed very coarse sudanophilic granules, localized in one area of the cytoplasm, similar to those seen in later basophils, of which $5 \%$ were present in the peripheral blood. Polymorphs showed strong sudanophilia.

4. Peroxidase reaction : $99 \%$ of the blast cells were negative, only one showing a faint localized tinge. Normal positivity in mature polymorphs.

TABLE II.-Results in Case 2

\begin{tabular}{|c|c|c|c|c|c|c|c|c|c|c|c|c|c|c|c|c|c|c|c|}
\hline $\begin{array}{l}\text { Type of } \\
\text { Culture }\end{array}$ & Date & $\begin{array}{c}\text { Haematological } \\
\text { Findings }\end{array}$ & Treatment & $\begin{array}{c}\text { Time of } \\
\text { Harvesting }\end{array}$ & Total & $\begin{array}{l}\text { Poly- } \\
\text { ploids }\end{array}$ & $>54$ & 54 & 53 & 52 & 51 & 50 & 49 & 48 & 47 & 46 & 45 & 44 & Comment \\
\hline $\begin{array}{l}\text { Peripheral } \\
\text { blood } \\
\text { without }\end{array}$ & $26 / 8 / 63$ & $\begin{array}{l}\text { Hb } 7 \text { g. W.C. } \\
134,360 \text {. Blasts } 85 \% \text {. } \\
\text { Myelocytes } 2 \% \% \\
\text { Erythroblasts } 1 \%\end{array}$ & $\begin{array}{l}\text { M.P. } 150 \mathrm{mg} . \\
\text { Prednisone } \\
40 \text { mg. daily }\end{array}$ & $\underset{\text { hours }}{24 \text { and }} 30$ & 17 & - & - & 3 & 2 & 1 & 1 & 1 & - & 1 & - & 7 & 1 & - & $\begin{array}{l}\text { big acrocentrics } \\
\text { and varying num- } \\
\text { bets of trisomies in } \\
\text { other groups. In }\end{array}$ \\
\hline $\begin{array}{l}\text { Peripheral } \\
\text { blood } \\
\text { without } \\
\text { P.H.A. }\end{array}$ & $29 / 8 / 63$ & $\begin{array}{l}\text { Hb 6.8 g. W.C. } \\
\text { 110,260. } \\
\text { Myelasts } 83 \% \\
\text { Erythrytes } 2 \% \\
\text { Erythoblasts } 2 \%\end{array}$ & " & $\begin{array}{c}24 \text { and } 28 \\
\text { hours }\end{array}$ & 34 & - & - & 4 & 4 & 2 & 2 & 3 & - & 1 & - & 15 & 1 & 2 & $\begin{array}{l}\text { all cells with } 50 \text { che } \\
\text { chromosomes the } \\
\text { chromosomes were } \\
\text { fuzzy, short, and } \\
\text { thick, despite var- } \\
\text { intign, }\end{array}$ \\
\hline $\begin{array}{l}5 . \\
\text { Peripheral } \\
\text { blood } \\
\text { without } \\
\text { P.H.A. }\end{array}$ & $13 / 9 / 63$ & $\begin{array}{l}\text { Hb } 5.4 \text { g. W.C. } 9,080 . \\
\text { Blasts 71\%. } \\
\text { Promyelocytes } 3 \% \\
\text { Erythroblasts } 3 \%\end{array}$ & . & $\underset{\text { hours }}{27 \text { and } 51}$ & 9 & - & - & 4 & 1 & 1 & - & - & - & - & - & 1 & 2 & - & $\begin{array}{l}\text { aations in tech- } \\
\text { nique. All cells } \\
\text { with } 46 \text { chromo- } \\
\text { somes were crisp } \\
\text { and sharp }\end{array}$ \\
\hline
\end{tabular}

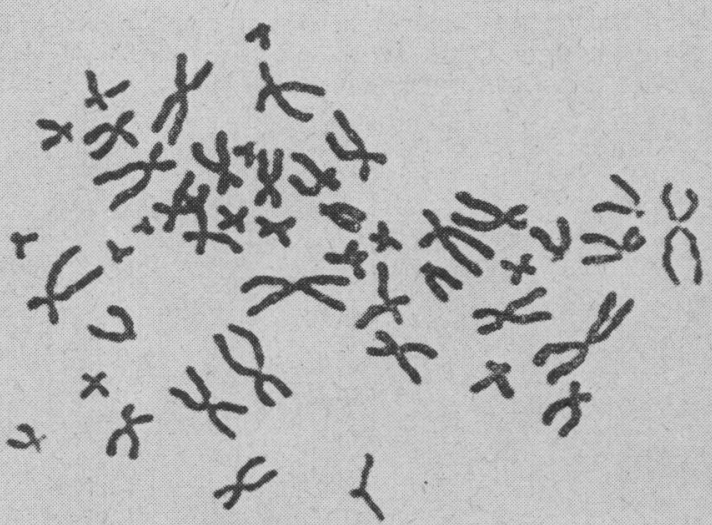

此邹
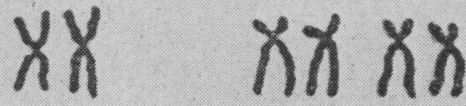

$1-2$

3

$4-5$

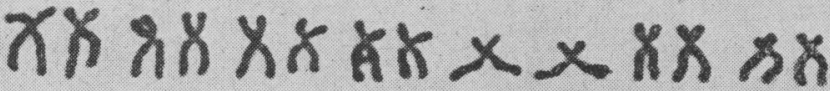
$6-12$
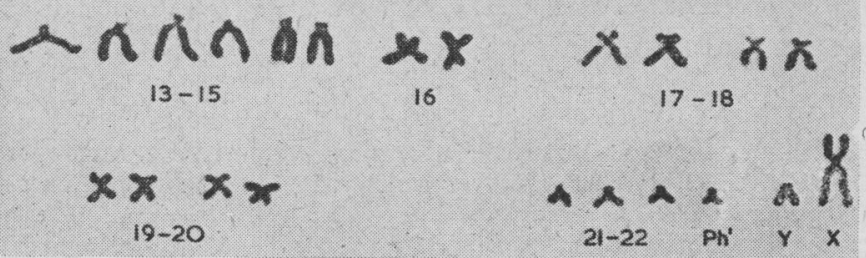

Fig. 3.-Diploid metaphase spread and karyotype from Case 2, showing single $\mathrm{Ph}^{1}$ chromosome.

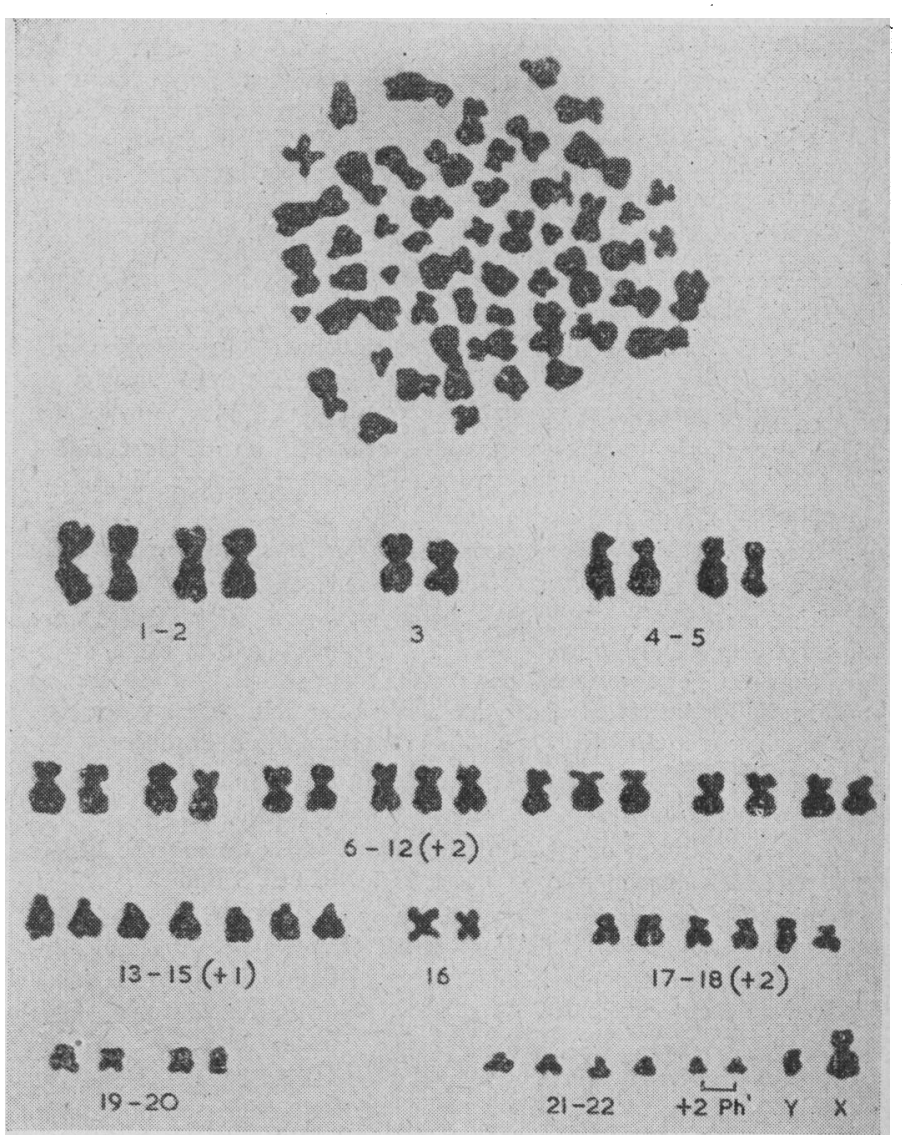

Frg. 4.- Hyperdiploid metaphase spread and karyotype from Case 2, showing 53 chromosomes, including two minute acrocentrics resembling 
5. Lactic dehydrogenase : tinge and moderately coarse granules $(=++$ positivity) in most blast cells.

6. Alpha-glycerophosphate dehydrogenase: tinge and fine granules $(=+$ positivity) in all blast cells.

7. Phosphorylase reaction: most blast cells showed brown granular positivity. Normal reaction in polymorphs.

On 22 October studies with tritiated thymidine showed that $2 \%$ of blast cells had marked thymidine uptake $(++++)$ and $1 \%$ low uptake $(t) ; 15 \%$ of myelocytes and promyelocytes showed varying degrees of thymidine incorporation.

Cytogenetic studies on repeated blood cultures from this case at early and late phases of the disease gave results shown in Table I and Figs. 1 and 2.

\section{Case 2}

A 35-year-old man was first seen and diagnosed as having chronic granulocytic leukaemia in July 1963. Clinical examination revealed anaemia and an enlarged spleen. When first examined his haemoglobin was $8.7 \mathrm{~g} . / 100 \mathrm{ml}$. and his total white-cell count 198,000, with $10 \%$ blast cells and promyelocytes. Treatment with busulphan was started and response was initially satisfactory, but within two months the proportion of blast cells in the peripheral blood rose sharply and a bone-marrow aspirate showed clear evidence of acute transformation of the disease with over $80 \%$ primitive cells Therapy was changed to mercaptopurine $(150 \mathrm{mg}$. daily) and prednisone $(40 \mathrm{mg}$. daily) and the patient was repeatedly transfused. After a fluctuating course with temporary phases of partial remission during the ensuing three months, rapid deterioration took place and he died on 11 November 1963.

Before treatment, cytochemical findings conformed to the pattern typical of chronic granulocytic leukaemia, with a negative alkaline phosphatase reaction in mature polymorphs and either a negative reaction or a diffuse tinge with or without fine granules in the primitive cells after P.A.S. staining.

On 29 September, when the white-cell count totalled 110,260, with $83 \%$ blast cells, cytochemistry was as follows:

1. Alkaline phosphatase score : 126.

2. P.A.S. score in blast cells : 141 ( $87 \%$ of blast cells showed fine, moderately coarse, or coarse granules and occasional blocks of P.A.S. positive material. Two types of blast cells were distinguished, a small one showing little or no P.A.S. positivity, and a larger primitive cell with varying degrees of granular P.A.S. positivity).

3. P.A.S. score in erythroblasts : 0 ( $100 \%$ negative).

4. Free iron score in erythroblasts: 90 , with irregularly scattered granules (normal range 6-76).

5. Sudan black $B$ reaction: blast cells were completely negative; promyelocytes and myelocytes showed normal positivity; mature granulocytes were strongly positive.

6. Peroxidase reaction: negative reaction in all blast cells; normal positivity in later granulocyte precursors and mature polymorphs.

7. Lactic dehydrogenase : most blast cells showed moderately coarse granules with some diffuse positivity $(=++$ positivity).

8. Alpha-glycerophosphate dehydrogenase: blast cells were either negative or showed only a faint cytoplasmic tinge $(= \pm$ positivity). Erythroblasts were weakly positive; promyelocytes and myelocytes showed numerous and moderately coarse granules; all mature granulocytes showed 5-10 cytoplasmic granules.

9. Phosphorylase reaction : brown granular positivity in most primitive cells.

Cytogenetic studies carried out at various times during the illness revealed results summarized in Table II and Figs. 3 and 4.

Combined autoradiographic and cytogenetic studies were performed on a blood sample taken on 17 October in an attempt to determine whether the persistent double cell lines in previous cytogenetic analyses could be correlated with differing cell types synthesizing D.N.A.

Autoradiographs on the peripheral blood initially presented the following pattern: $2.5 \%$ blast cells showed high grain counts $(++++)$ and $5.5 \%$ low grain counts $(+) ; 3 \%$ of promyelocytes and myelocytes showed varying degrees of uptake; $7.5 \%$ erythroblasts also showed some uptake, $5.5 \%$ having high grain counts
$(++++)$. There was thus an initial ratio of labelled granulocyte precursors to labelled erythroblasts of 11 to 7.5 .

A second autoradiographic study after 24 hours' culture showed an increase in proportion of erythroblasts having uptake (Fig. 5), the ratio of labelled granulocyte precursors to labelled erythroblasts being 7 to 30 . At this time cytogenetic analysis showed the presence of two cell lines; 15 spreads were counted, six falling in the 50-54 cell line and nine in the 44-47 line. A third autoradiographic study after 48 hours' culture showed almost complete absence of labelling in erythroblasts although numerous granulocyte

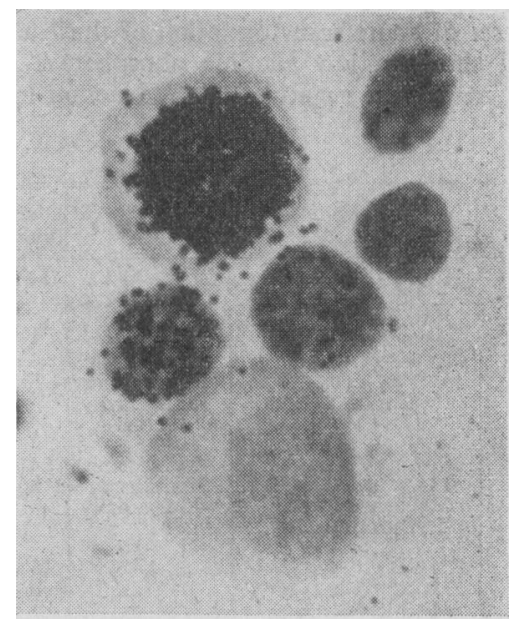

Fig. 5.-Case 2. A group of five erythroblasts and one myelocyte at 24 hours of culture. Three of the red-cell precursors show different degrees of thymidine incorporation. $(\times 1,800$.

precursors showed uptake (Fig. 6). The ratio of labelled granulocyte precursors to labelled erythroblasts was now 17 to 1 . Further spreads for chromosome analysis made at the same time yielded only eight countable figures, but all these fell in the 44-47 group and no figures of the 50-54 cell line could be seen.

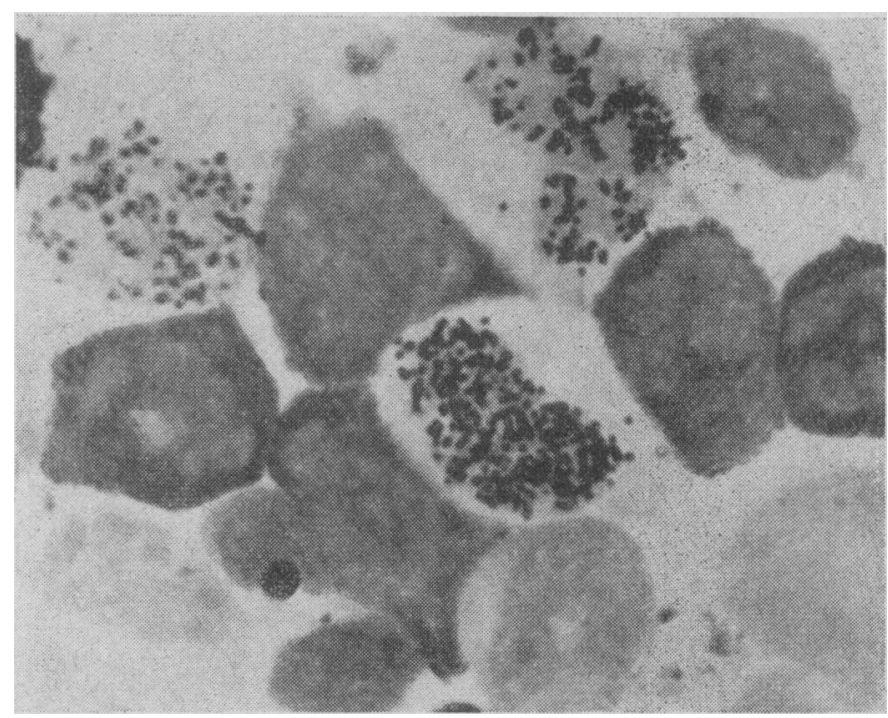

FIG. 6.-Case 2. Granulocyte precursors at various stages of maturation after 48 hours of culture. Thymidine uptake is shown in three. The preparation is counterstained by P.A.S. $(\times 1,800$.)

\section{Case 3}

A 39-year-old man was diagnosed as having chronic granulocytic leukaemia in December 1960, at which time his haemoglobin was 6.5 g., and white-cell count 386,000 , with $7 \%$ blast cells. After a course of radiotherapy to the spleen, he was treated with busulphan, to which he showed a partial response. His condition remained more or less unchanged until March 1963, when he began to show increasing evidence of an acute transformation of his leukaemia. 
On 21 March his total white-cell count was 31,000, with $12 \%$ blast cells. Cytochemical investigations were carried out on 8 April, when his white-cell count was 47,000 and his blast cells numbered $28 \%$. Previous cytochemical findings had conformed to the pattern usually seen in chronic granulocytic leukaemia:

1. Alkaline phosphatase score : 128.

2. P.A.S. score on blast cells : $110(60 \%$ of the primitive cells showed fine, moderately coarse, or coarse granules and blocks).

3. P.A.S. score on erythroblasts : 118 (23\% showed very intense diffuse positivity $(=+++$ positivity).

4. Free iron score on erythroblasts : 136 (normal range 7-76); a proportion of erythroblasts showed concentric rings of siderotic granules similar to the appearance seen either in erythraemic myelosis or in refractory sideroblastic anaemia.

5. Sudan black $B$ reaction : $97 \%$ of blasts showed a negative reaction, two faint localized positivity, and one strong localized reactivity. Polymorphs were strongly positive.

6. Peroxidase reaction : $99 \%$ of blasts were negative, only $1 \%$ showing faint localized positivity; normal reaction in later granulocytes.

7. Lactic dehydrogenase : blast cells showed moderately coarse granules $(=++$ positivity) ; $30 \%$ of mature polymorphs showed a few fine granules.

8. Succinic dehydrogenase: mostly fine granules or tinge in blasts $(=+$ positivity).
9. Phosphorylase reaction : faint blue tinge in a proportion of blast cells; basophils showed blue granules.

Studies with tritiated thymidine gave the following results: $15.6 \%$ of blast cells showed high grain counts $(+++$ and ++++ positivity); $1 \%$ of blast cells showed low grain counts ( + and ++ positivity) $; 1.8 \%$ erythroblasts showed strong thymidine uptake $(t++$ and $t+++$ positivity) and $0.2 \%$ only moderate uptake $(++$ positivity). $1.8 \%$ promyelocytes and myelocytes showed varying, but usually weak, degrees of thymidine uptake.

Cytogenetic studies gave results summarized in Table III and in Fig. 7.

\section{Case 4}

A man of 32 was referred to this department in December 1962 with a diagnosis of leukaemia. Clinical examination revealed pallor, enlargement of lymph nodes, liver $2 \mathrm{~cm}$. and spleen $8 \mathrm{~cm}$. below the costal margin. A blood count showed haemoglobin $8 \mathrm{~g}$., total leucocyte count 270,000 , with $66 \%$ blasts, $1 \%$ promyelocytes, $4 \%$ myelocytes and metamyelocytes, $12 \%$ polymorphs, $8 \%$ basophils, $7 \%$ lymphocytes, and $2 \%$ monocytes. Platelets numbered 65,000/c.mm He was treated with blood transfusions, mercaptopurine, and pred nisone, and on this combination of therapy his total leucocyte count progressively decreased to 3,320 , although the blast cells never disappeared from the peripheral blood.

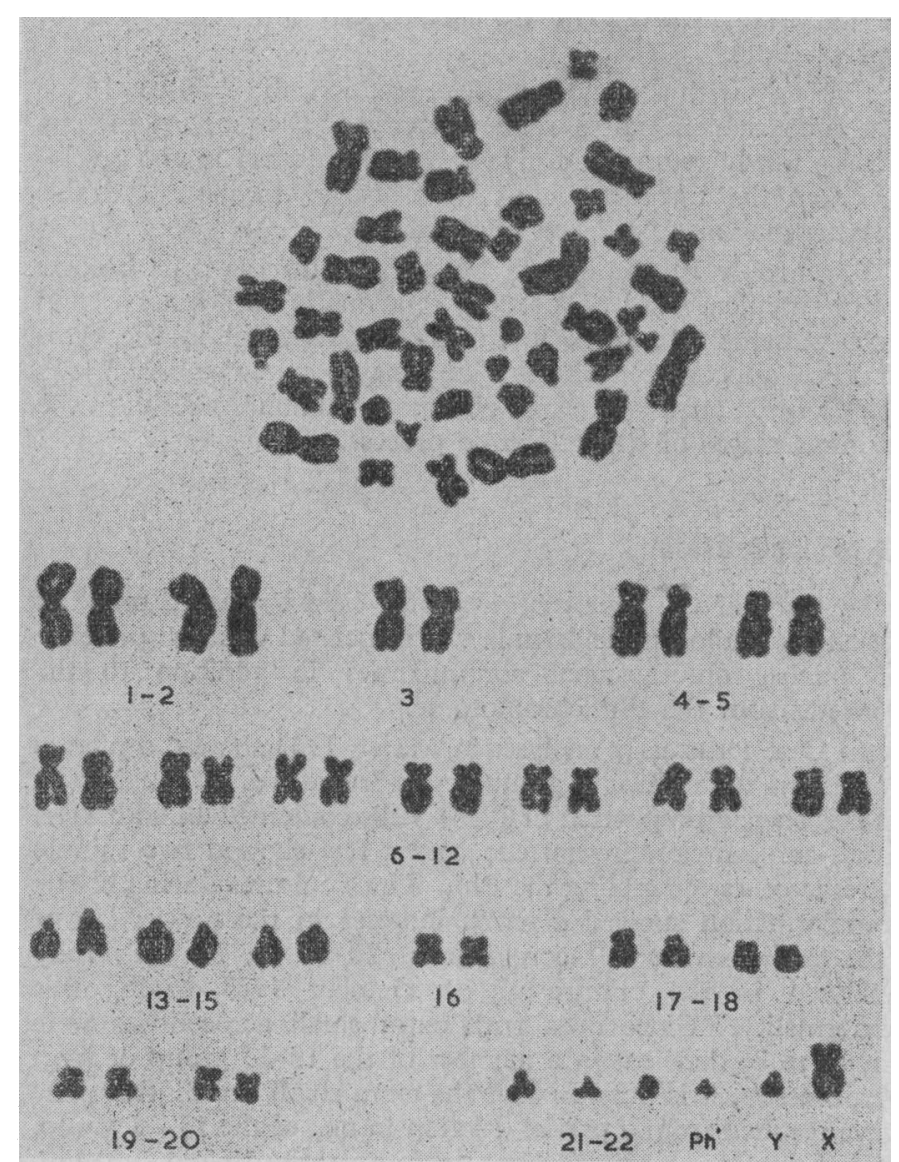

Fig. 7.-Diploid metaphase spread and karyotype from Case 3, showing single $\mathrm{Ph}^{1}$ chromosome.
When he was first seen his alkaline phosphatase score was 28, but it subsequently rose to 79 on 5 March and to 140 on 14 May. A complete series of cytochemical investigations was carried out on 28 May, when his total white-cell count was 23,580 , with $79 \%$ blast cells.

1. Alkaline phosphatase score: 160.

2. P.A.S. score on blast cells: $63(60 \%$ of the primitive cells were negative, $36 \%$ showed fine or moderately coarse granules, and 4\% blocks of P.A.S.-positive material: the latter were presumably early basophils, since the same proportion of primitive cells showed a positive reaction with toluidine blue).

3. P.A.S. score on erythroblasts : 6 ( $97 \%$ were completely negative).

4. Free iron score on erythroblasts : 64 (normal range 7-76).

5. Sudan black B reaction : $96 \%$ of primitive cells were negative and $4 \%$ showed coarse positive granules similar to those seen in mature basophils; mature polymorphs were strongly positive.

6. Peroxidase reaction : $99 \%$ of blasts were negative and $1 \%$ showed a faint tinge; normal reaction in polymorphs.

7. Lactic dehydrogenase : coarse granular positivity $(=+++$ positivity) in most blast cells ; $20 \%$ of polymorphs showed a few fine granules.

8. Succinic dehydrogenase : moderately coarse positivity in the majority of primitive cells (from ++ to +++ positivity); polymorphs appeared to be negative.

Autoradiographic studies with tritiated thymidine showed the following : $4.4 \%$ blast cells showed high grain counts $(+++$ to +++ positivity); $0.8 \%$ blast cells showed low grain counts $(+$ to ++ positivity) $; 0.4 \%$ promyelocytes showed moderate thymidine uptake $(++$ positivity).

Chromosome studies on this patient, reported and illustrated by Hammouda (1963), showed abnormalities as summarized in Table IV.

\section{Discussion}

The findings obtained from a combination of cytochemical, autoradiographic, and cytogenetic studies on the four cases 
described above have shown the existence of certain rather striking features, some common to all four cases.

The possible role of previous treatment with $x$-rays or cytotoxic drugs in the development of these features must remain, for the present, speculative. So far as the cytochemical changes are concerned, our own experience with considerable numbers of leukaemic patients studied throughout the course of their diseases has not suggested that any specific cytochemical changes are induced by antimitotic therapy, apart from a tendency for abnormalities to diminish when therapy is effective. Even administration of steroids, which causes an increase in leucocyte alkaline phosphatase in normal subjects, scarcely influences the levels in chronic granulocytic leukaemia. Chromosomal damage after irradiation and use of cytotoxic drugs is, of course, well recognized, but the changes usually involve the appearance of acentric fragments and chromatid breaks of emerged from studying the P.A.S. reaction was the fact that two different types of blast cells were present in the peripheral blood, one large showing coarse P.A.S. positivity and the other small with little or no positivity. Both these cells were negative to Sudan black and peroxidase, and it is impossible to state whether the difference in size and P.A.S. content reflected a different cytological origin.

In all four cases the Sudan black and peroxidase reactions appeared to be negative in the more primitive cells, and, contrary to the findings obtained in acute myeloblastic leukaemia, positivity was confined to later granulocyte stages. Mature polymorphs always showed strong positivity with both reactions.

The results obtained with the various dehydrogenases are less easy to interpret because, hitherto, studies on these enzymes have been carried out on a limited scale and variations in the

TABLE IV.-Results in Case 4

\begin{tabular}{|c|c|c|c|c|c|c|c|c|c|c|c|c|}
\hline $\begin{array}{l}\text { Type of } \\
\text { Culture }\end{array}$ & Date & $\begin{array}{c}\text { Haematological } \\
\text { Findings }\end{array}$ & Treatment & $\begin{array}{c}\text { Time of } \\
\text { Harvesting }\end{array}$ & Total & $>47$ & 47 & 46 & 45 & 44 & $<44$ & $\begin{array}{c}\text { Abnormalities } \\
\text { Detected }\end{array}$ \\
\hline $\begin{array}{l}\text { Peripheral } \\
\text { blood with- } \\
\text { out P.H.A. }\end{array}$ & $28 / 5 / 63$ & $\begin{array}{l}\text { Hb } 8 \cdot 8 \mathrm{~g} . \\
\text { W.C. } 23,580 . \\
\text { Blasts } 79 \% . \\
\text { Platelets } \\
80,000\end{array}$ & $\begin{array}{l}\text { M.P. } 75 \mathrm{mg} \text {. } \\
\text { Prednisone } \\
4 \theta \text { mg. daily }\end{array}$ & $\begin{array}{l}32 \text { and } 48 \\
\text { hours }\end{array}$ & 60 & - & 14 & 23 & 12 & 4 & 7 & $\begin{array}{l}43 \text { cells had } 2 \text { unusually small acrocentrics } \\
\text { similar to Phi } 17 \text { had only } 1 \text { minute } \\
\text { acrocentric. All cells with } 47 \text { chromosomes } \\
\text { had an extra small acrocentric }\end{array}$ \\
\hline $\begin{array}{c}2 . \\
\text { Bone- } \\
\text { marrow }\end{array}$ & $18 / 6 / 63$ & $\begin{array}{l}\text { Hb. 8.1 g. } \\
\text { W.C. } 67,400 . \\
\text { Blasts } 97 \%\end{array}$ & $\begin{array}{l}\text { M.P. } 100 \mathrm{mg} . \\
\text { Prednisone } \\
40 \mathrm{mg} . \text { daily }\end{array}$ & $1 \frac{1}{2}$ hours & 9 & - & 2 & 5 & - & 1 & 1 & $\begin{array}{l}7 \text { had } 2 \text { unusually small acrocentrics as described } \\
\text { above. Both cells with } 47 \text { chromosomes had } \\
\text { an extra small acrocentric }\end{array}$ \\
\hline
\end{tabular}

All cells from the above preparations were $\mathrm{Ph}^{1}+$. Peripheral blood cultures on 28 May with P.H.A. showed a proportion of cells which were $\mathrm{Ph}^{1}-$ and had normal karyotypes.

irregular distribution (Biesele, 1958; Tough et al., 1960 ; Wahrman and Robinson, 1963), whereas the cytogenetic changes reported here are of a more consistent character and a different kind.

\section{Cytochemical Results}

Confirmation of previous observations is given by the finding in all four cases of alkaline phosphatase scores well above the range usually found in chronic granulocytic leukaemia. The three undoubted cases of terminal transformation when previously examined had shown the characteristic low levels usually found in the chronic phase, while the fourth showed a progressive increase in the reaction from the initial figure of 28 to the final score of 160 .

The second interesting and again confirmatory finding was the occurrence of moderately coarse and coarse granular P.A.S. positivity in primitive cells, which, prior to the onset of the blastic transformation, had shown in the first three cases a negative reaction or faint diffuse positivity with or without fine granules.

It is conceivable that a proportion of the more P.A.S.-positive cells were early basophils as in Cases 1 and 4, an assumption supported by the finding of cells showing positivity when stained with toluidine blue (Case 4) and by the presence of coarse and tightly packed sudanophilic granules, in every way similar to those seen in later, cytologically identifiable basophils.

In Case 3 it is possible that some of the coarsely P.A.S.positive primitive cells could have been early red-cell precursors, a hypothesis which finds some justification in the strong P.A.S. positivity found in late and intermediate erythroblasts. The abnormal P.A.S. positivity in erythroblasts combined with an increase in free intracytoplasmic iron suggested the existence of an erythraemic component in the terminal blastic development.

Case 2 did not, however, have any early or late basophils, and the numerous erythroblasts in the bone-marrow and those in the peripheral blood did not show any P.A.S. positivity, making it appear less likely that the P.A.S.-positive primitive cells were either basophil precursors or proerythroblasts. What degree and intensity of the reaction are difficult to assess. However, it appeared as if in Cases 1,2, and 3 the reactions were weaker than those seen in other primitive cells, whether normal or leukaemic, while in Case 4 the blast cells, which contained less P.A.S. positivity, showed more intense dehydrogenase reactions. It is arguable, therefore, that the increase in glycogen in the blast cells may follow upon a reduction in the availability of enzymes involved in the breakdown and utilization of carbohydrate.

Similarly with the phosphorylase reaction, the absence of blue positivity, which expresses the activity of the enzyme in producing newly synthesized glycogen and is found in the myeloblasts in the chronic phase of the disease, suggests that this enzyme may also be decreased terminally.

Presumably as the disease progresses and the cells become more atypical and abnormal, enzymatic deficiencies and derangements take place and these are reflected in the cytochemical appearances described and may possibly be linked with the observed enhancement of chromosomal abnormalities in the terminal stages of the leukaemic process.

\section{Cytogenetic Results}

In three of the four cases reported here the acute phase of chronic granulocytic leukaemia was associated with the presence of further chromosomal abnormalities in addition to the persistence of the $\mathrm{Ph}^{1}$ chromosome.

In Case 1 the early analyses in March 1963 showed a picture consistent with chronic granulocytic leukaemia, although even at this stage a proportion of $\mathrm{Ph}^{1}+$ cells contained an additional small acrocentric chromosome, and a few showed two minute chromosomes resembling the $\mathrm{Ph}^{1}$. Later cultures during blastic transformation showed a sharp increase in the proportion of cells with extra small acrocentrics, 28 of the 30 cells fully analysed in the culture of 31 October 1963 having this abnormality. Since cells with extra small acrocentrics were found to be deficient in a member of the 13-15 group of large acrocentries, it is possible that the extra small acrocentrics may have resulted from a partial deletion in one of the 13-15 group, giving rise to a new cell line, predominantly diploid but with an abnormal karyotype. At the same time it is interesting to 
note that in 10 of the 30 figures a second minute acrocentric resembling $\mathrm{Ph}^{1}$ was present.

Case 2 showed two clearly distinguished cell lines, one with a diploid modal number and only a single $\mathrm{Ph}^{1}$ chromosome, and the second with 50-54 chromosomes, including invariably two minute acrocentrics resembling the $\mathrm{Ph}^{1}$ chromosome and having seven small and seven large acrocentrics together with varying numbers of trisomies in other groups. The chromosomes of the second cell line were notably thick, short, and weakly staining, with outlines less crisp than those of the chromosomes from the first cell line-an appearance like that described by Lewis et al. (1963) in a high proportion of hyperdiploid cells from a case of multiple myelomatosis. The disappearance of the 50-54 cell line after 48 hours' culture was paralleled by the disappearance of autoradiographically labelled erythroblasts at this period of culture, and it may well be that this hyperdiploid cell line represented an erythroblastic component. If so, this observation would tend to confirm the supposition that erythroblasts may carry the $\mathrm{Ph}^{1}$ chromosome in chronic granulocytic leukaemia. lines.

Case 3 showed a diploid $\mathrm{Ph}^{1}+$ karyotype without new cell

Case 4 showed, as previously reported (Hammouda, 1963), a high proportion of cells with two minute acrocentric chromosomes similar to the $\mathrm{Ph}^{1}$ chromosome, and a smaller proportion with an additional small acrocentric and a total number of 47 chromosomes.

\section{Observations on Relation of Leucocyte Alkaline Phosphatase and Chromosome 21}

If the defect in leucocyte alkaline phosphatase in chronic granulocytic leukaemia were secondary to the loss of genetic material from the chromosome 21 involved in the $\mathrm{Ph}^{1}$ change, one might expect the sharp rise in leucocyte phosphatase in blastic crisis to be associated with reappearance of previously lost material, perhaps in the form of additional small acrocentrics. Observations such as those of Alter et al. (1963) have shown increased levels of leucocyte alkaline phosphatase in mongolism, and might be taken to support the hypothesis that the gene determinant for the enzyme is carried by chromosome 21. Our results do not, however, show consistent increase in the number of small acrocentrics, possibly involving chromosome 21 , in the stage of acute transformation with rising leucocyte alkaline phosphatase.

Case 3, for example, continued to display a diploid $\mathrm{Ph}^{1}+$ karyotype despite the rise in phosphatase score to well above normal limits, while in Case 2 the cell line believed from autoradiographic evidence to be granulocytic also remained diploid with a $\mathrm{Ph}^{1}$ chromosome and no additional small acrocentrics. It is true that Case 1 showed a high proportion of cells with an extra small acrocentric, but we have already given reasons for believing that this may have resulted from a partial deletion in one of the 13-15 group of chromosomes, and would not therefore be expected to influence the leucocyte phosphatase level, which, in any case, showed a much less substantial rise in this patient than in the other three. The findings in Case 4 are even more difficult to explain on the gene hypothesis proposed, since the high leucocyte alkaline phosphatase score was associated with loss rather than gain of small acrocentric material, many diploid cells having two minute chromosomes resembling $\mathrm{Ph}^{1}$, and all except 2 of the 16 cells with 47 chromosomes also having two $\mathrm{Ph}^{1}$ chromosomes. The diploid cells thus appeared to have a further loss of small acrocentric D.N.A., and the hyperdiploid ones showed no increase over the morphological chromosome content of chronic granulocytic leukaemia cells apart from the second $\mathrm{Ph}^{\mathbf{1}}$.

It is therefore clear that in the circumstances of the present study a sharp rise in leucocyte alkaline phosphatase content may occur without any associated increase in morphologically recognizable chromosome material atributable to the small acrocentric group and, indeed, without any obvious karyotypic change from the picture in the chronic phase of the disease. Any simple hypothesis directly relating the morphological defect of the $\mathrm{Ph}^{1}$ chromosome to functional deficiency of leucocyte alkaline phosphatase would thus appear untenable.

\section{Summary}

Four cases of chronic granulocytic leukaemia in blastic crisis have been studied by cytochemical, autoradiographic, and cytogenetic methods.

Cytochemically all were characterized by rise in alkaline phosphatase levels in mature polymorphs, and by coarse P.A.S. positivity in the emerging blast cells.

Case 3 showed no chromosomal change from the typical picture of chronic, granulocytic leukaemia, but the remaining cases showed other features: Case 1 having a high proportion of cells with an extra small acrocentric but a loss of one large acrocentric; Case 2 having two separate cell lines, one diploid and the other with 50-54 chromosomes; and Case 4 having the frequent presence of two minute chromosomes resembling $\mathrm{Ph}^{1}$ in a predominantly diploid picture. In addition to the abnormalities described, most cells from Cases 1 and 2 contained the $\mathrm{Ph}^{1}$ chromosome, and many also showed a second minute acrocentric of similar appearance.

Despite the increase in leucocyte alkaline phosphatase, there was no apparent replacement of the $\mathrm{Ph}^{1}$ defect in chromosome 21 either by a return to the normal complement of small acrocentrics or by the consistent appearance of extra small acrocentrics possibly supplementary to the 21 pair.

We wish to acknowledge with gratitude the technical assistance of Mr. R. J. Flemans, Miss S. Hardcastle, and Miss C. Evans.

\section{REFERENCES} Adams, A., Fitzgerald, P. H., and Gunz, F. W. (1961). Brit. med. F., 2,
1474.

Alter, A. A., Lee, S. L., Pourfar, M., and Dobkin, G. (1963). Blood, 22, 165

Biesele, J. J. (1958). Ann. N.Y. Acad. Sci., 71, 1054.

Court Brown, W. M., and Tough, I. M. (1963). Advanc. Cancer Res., $7,351$. Fischer, R., Lorbacher, P., and Schumacher, K. (1963). Klin. Wschr., 41,
669.

Hammouda, F. (1963). Lancet, 2, 410.

Hayhoe, F. G. J. (1963). In L. Whitby and C. J. C. Britton's Disorders of the Blood, 9th ed., p. 131. Churchill, London.

- and Quaglino, D. (1958). Brit. F. Haemat., 4, 375.

- (1960). Ibid., 6, 381.

Acute Leukaemias. (1964). The Cytology and Cytochemistry of Acute Leukaemias. A Study of 140 Cases. H.M.S.O., London.

Kaplan, E., Zuelzer, W. W., and Mouriquand, C. (1954). Blood, 9, 203.

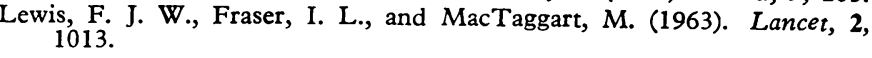

McManus, J. F. A. (1946). Nature (Lond.), 158, 202.

Moorhead, P. S., Nowell, P. C., McIlman, W. J., Battips, D. M., and Hungerford, D. A. (1960). Exp. Cell. Res., 20, 613.

Nowell, P. C., and Hungerford, D. A. (1961). F. Nat. Cancer Inst., 27,

Quaglino, D. (1961a). Ph.D. Thesis, Camb. Univ. (1961b). Proceedings of the VIII Congress of the European Society
of Haematology, vol. 1, paper 20 .

- and Flemans, R. (1958). Lancet, 2, 1020.

and Hayhoe, F. G. J. (1959). F. Path. Bact., 78, 521. (1960). Brit. f. Haemat., 6, 26.

(1962). Nature (Lond.), 194, 929.

Sheehan, H. L., and Storey, G. W. (1947). F. Path. Bact., 59, 336.

T,io, J. H., and Whang, J. (1962). Stain Technol., 37, 17.

Tough, I. M., Buckton, K. E., Baikie, A. G., and Court Brown, W. M. (1960). Lancet, 2, 849.

Wahrman, J., and Robinson, E. (1963). Ibid., 1, 505. 